\title{
EMANSIPASI WANITA DI NEGARA ISLAM (Pemikiran Qasim Amin di Mesir)
}

\author{
Oleh: Hasri \\ Dosen Jurusan Tarbiyah STAIN Palopo \\ E-mail: prodimat stainplp@yahoo.co.id
}

\begin{abstract}
Abstrak:
Zaman dahulu wanita selalu dianggap lemah, mengerjakan segala macam pekerjaan tidak cekatan dan tidak terampil, hanya bisa berkata "boleh" ataupun "iya" apabila kaum pria menyeuruh mereka. Tetapi sekarang, wanita dapat berkata "tidak" apabila ada hal yang tidak sesuai dengan keinginannya yang dikatakan oleh kaum pria. Itulah salah satu demokrasi yang ditonjolkan oleh wanita karena sekaranglah waktunya untuk bangkit dan berani menyuarakan aspirasi mereka. Adapun makna emansipasi wanita adalah perjuangan sejak abad ke-14 M dalam rangka memperoleh persamaan hak dan kebebasan seperti hak kaum laki-laki. Jadi para penyeru emansipasi wanita menginginkan agar para wanita disejajarkan dengan kaum pria di segala bidang kehidupan, baik dalam pendidikan, pekerjaan, perekonomian maupun dalam pemerintahan. Mesir merupakan negara Islam yang pertama menyadari hal ini, oleh karena itu orang-orang Mesirlah yang pertama mengadakan kontrak dengan dunia barat. Diantara jajaran pemikir-pemikir Islam di Mesir yang pertama memunculkan ide-ide emansipasi wanita adalah Al-Tahtawy. Tetapi pemikir yang mempunyai perhatian besar dan menghususkan dirinya untuk membicarakan hal ini adalah Qasim Amin.
\end{abstract}

Kata Kunci: Emansipasi, Wanita, Negara Islam

\section{Pendahuluan}

Zaman dahulu wanita selalu dianggap lemah, mengerjakan segala macam pekerjaan tidak cekatan dan tidak terampil, hanya bisa berkata "boleh" ataupun "iya" apabila kaum pria menyeuruh mereka. Tetapi sekarang, wanita dapat berkata "tidak" apabila ada hal yang tidak sesuai dengan keinginannya yang dikatakan oleh kaum pria. Itulah salah satu demokrasi yang ditonjolkan oleh wanita karena sekaranglah waktunya untuk bangkit dan berani menyuarakan aspirasi mereka. Contohnya saja, sekarang ini banyak wanita yang dapat mencapai karier mereka dengan sukses. Disisi lain, mereka melupakan keluarga mereka ataupun suami mereka demi mengejar karier tersebut.

Apakah contoh di atas merupakan suatu hal yang wajar dilakukan oleh seorang wanita dikarenakan suatu alasan yaitu emansipasi? 


\section{Pembahasan}

1. Pengertian menasipasi

Emansipasi berasal dari bahasa latin "emancipatio" yang artinya pembebasan dari tangan kekuasaan. Di zaman Romawi dulu, membebaskan seorang anak yang belum dewasa dari kekuasaan orang tua, sama halnya dengan mengangkat hak dan derajatnya (Newryl, 2011).

Adapun makna emansipasi wanita adalah perjuangan sejak abad ke-14 $\mathrm{M}$ dalam rangka memperoleh persamaan hak dan kebebasan seperti hak kaum laki-laki. Jadi para penyeru emansipasi wanita menginginkan agar para wanita disejajarkan dengan kaum pria di segala bidang kehidupan, baik dalam pendidikan, pekerjaan, perekonomian maupun dalam pemerintahan.

2. Munculnya emansipasi di Mesir dan pengaruhnya

Mesir merupakan negara Islam yang pertama menyadari hal ini, oleh karena itu orang-orang Mesirlah yang pertama mengadakan kontrak dengan dunia barat. Diantara jajaran pemikir-pemikir Islam di Mesir yang pertama memunculkan ide-ide emansipasi wanita adalah Al-Tahtawy. Tetapi pemikir yang mempunyai perhatian besar dan menghususkan dirinya untuk membicarakan hal ini adalah Qasim Amin.

Meskipun ide emansipasi wanita Qasim Amin ini belum dapat diterima pada zamannya, namun mempunyai pengaruh besar dalam rangka kemajuan bangsa Mesir khususnya dan dunia Islam pada umumnya. Wanita merupakan bagian terbesar dari komunitas masyarakat umum. Apabila mereka baik, niscaya masyarakat pun akan menjadi baik. Sebaliknya, apabila mereka rusak, masyarakat pun akan rusak. Sungguh apabila benar-benar memahami agama, hukum dan syariat Allah niscaya mereka akan mampu melahirkan generasi-generasi baru yang tangguh dan berguna bagi umat seluruhnya (Susenos, 2010).

Dalam masa kebudayaan jahiliyah sebelum datangnya Islam, wanita dianggap sangat rendah dan hina bahkan tidak sedikit ketika lahir anak perempuan akan dikubur hiduphidup. QS: An Nahl/16 : 58-59: 


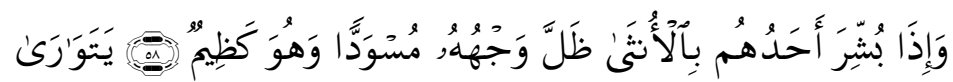

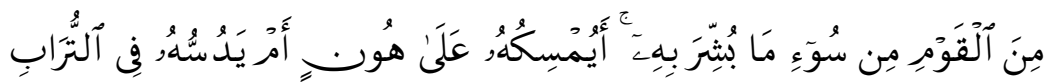

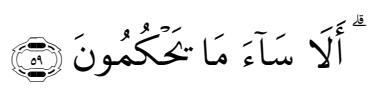

58. Dan apabila seseorang dari mereka diberi kabar dengan (kelahiran) anak perempuan, hitamlah (merah padamlah) mukanya, dan dia sangat marah.

59. la menyembunyikan dirinya dari orang banyak, disebabkan buruknya berita yang disampaikan kepadanya. apakah dia akan memeliharanya dengan menanggung kehinaan ataukah akan menguburkannya ke dalam tanah (hidup-hidup) ?. Ketahuilah, alangkah buruknya apa yang mereka tetapkan itu.

Pemuka-pemuka Islam mulai mencari dan mengkaji sebab-sebab keterbelakangan ini. Berbagai jawaban telah dikemukakan oleh para tokoh berdasarkan pengamatan dan analisa mereka. Menurut mereka banyak hal yang menyebabkan umat Islam tertinggal dibandingkan dengan orang barat. Salah satu diantaranya karena tidak terdidiknya kaum wanita. Kaum wanita memiliki kedudukan yang tinggi di dalam Islam dan memiliki hak yang sama dalam mengamalkan agama. Dimana Allah SWT telah memperlakukan mereka dan membebankan hukum-hukum syariat sesuai dengan fitrah penciptaannya. Hal ini masuk dalam keumuman firman-Nya: QS. Al-Baqarah/2 : 286:

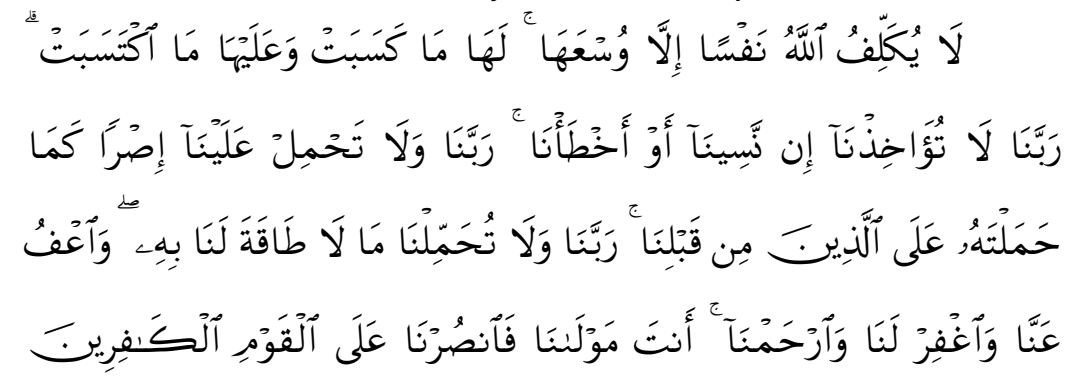

픈

286. Allah tidak membebani seseorang melainkan sesuai dengan kesanggupannya. ia mendapat pahala (dari kebajikan) yang diusahakannya dan ia mendapat siksa (dari 
kejahatan) yang dikerjakannya. (mereka berdoa): "Ya Tuhan kami, janganlah Engkau hukum kami jika kami lupa atau kami tersalah. Ya Tuhan kami, janganlah Engkau bebankan kepada kami beban yang berat sebagaimana Engkau bebankan kepada orang-orang sebelum kami. Ya Tuhan kami, janganlah Engkau pikulkan kepada kami apa yang tak sanggup kami memikulnya. beri ma'aflah Kami; ampunilah Kami; dan rahmatilah kami. Engkaulah penolong kami, Maka tolonglah kami terhadap kaum yang kafir."

Allah maha adil dalam menentukan syariat-Nya dan maha bijaksana dalam meletakkan hukum-hukum-Nya untuk mereka. Allah SWT telah memuliakan mereka dengan berbagai bentuk dan cara, diantaranya:

1) Allah SWT memerintahkan mereka untuk tinggal di rumah-rumah mereka, agar terjaga kehormatan mereka;

2) Allah SWT tidak membebankan mereka untuk mencari nafkah bagi anak-anak mereka;

3) Kaum wanita diperintahkan untuk menutup seluruh tubuh mereka;

4) Kaum wanita tidak boleh bepergian dalam sebuah safar melainkan harus disertai mahram, melihat kondisi wanita yang lemah serta membutuhkan perlindungan dan pemeliharaan;

5) Urusan talak perceraian tidak diserahkan kepada wanita;

6) Tidak diwajibkan bagi wanita untuk ikut memikul amanat jihad fi sabilillah sebagaimana telah dibebankan kepada kaum lelaki.

Beberapa bentuk perlakuan Allah SWT terhadap kaum wanita di atas, jika dipelajari dan ditinjau dengan akal yang sehat dan fitrah yang bersih, akan diketahui bahwa itu semua merupakan cara untuk menjaga eksistensi wanita. Kesemuanya itu adalah perlakuan yang bijak dan adil, sesuai dengan kodrat mereka. Namun berapa dari wanita yang memahami diri dan kemuliaannya?

Sekalipun gerakan emansipasi wanita ini mendapat tantangan yang kuat, namun gerakan ini sangat berpengaruh dari warga Mesir terutama masa sesudahnya. Pengaruh tersebut antara lain menimbulkan beberapa gerakan sebagai berikut:

1) Adanya kesadaran baru di kalangan masyarakat tentang perlunya pendidikan wanita;

2) Mulai adanya kelonggaran jilbab; 
111 | al-Khwarizmi, Volume II, Edisi 2, Oktober 2014, Hal. 107 - 114

3) Adanya keluhan dari kalangan pemuda tentang sistem perkawinan yang berlaku. Mereka mengharapkan adanya perubahan sistem perkawinan tersebut;

4) Adanya perhatian pemerintahan dan para pemuda negara terhadap undang-undang yang berlaku di peradilan agama. (Qasim Ain, 2011)

3. Pandangan pembela dan pencelaemansipasi wanita

Di Mesir sendiri negara pertama kali yang mempropagandakan gerakan emansipasi wanita ini banyak orang yang terpengaruh dengan pemikiran Rif'at ini yang kebanyakan mereka adalah para intelektual muslim hasil didikan barat dan orang nasrani, diantaranya adalah:

1) Markus Fahmi (w. $1374 \mathrm{M}$ );

2) Ahmad Luthfi As-Sayyid (w. 1382 M);

3) Qasim Amin (w. $1326 \mathrm{M}$ );

4) Ratu Nazily Abdurrahman Shabry;

5) Sa'd Zaghlul (w. 1346 M);

6) Huda Sya'rawi (w. 1367 M).

Para intelektual ini bahu membahu mendakwahkan gerakan iblis ini untuk mengelabui wanita-wanita muslimah dengan menggunakan surat kabar, sarana pertama dan paling utama serta paling efektif untuk menyebarkan gerakan ini. Maka muncullah surat kabar dengan nama "Majalah As-Sufur (majalah pornografi)" pada tahun $1318 \mathrm{M}$, yang isinya tidak lain merusak wanita muslimah melalui halhal berikut:

1) Menampilkan gambar-gambar wanita seksi;

2) Campur baur antara laki perempuan dalam diskusi dan rapat-rapat;

3) Pemikiran sesat tentang "wanita adalah partner laki-laki" maksudnya bahwa wanita itu sama dengan lelaki dalam semua hal";

4) Menjelek-jelekkan ajaran Islam bahwa lelaki adalah pemimpin bagi wanita;

5) Menampilkan mode dan busana ala barat model kolam renang bagi wanita;

6) Menampilkan gambar tempat-tempat hiburan, kafe, bar, dll;

7) Menampilkan kisah-kisah mesum dan porno yang merusak kehormatan wanita;

8) Menyanjung bintang film, penyanyi, artis, dll. (Muslimah, 2011). 


\section{Penerapan emansipasi wanita}

Perkembangan pemikiran Islam kontemporer yang luar biasa saat ini sesungguhnya dapat diklasifikasikan dalam 5 model kecenderungan:

Pertama, fundamentalis. Yaitu model pemikiran yang sepenuhnya percaya pada doktrin Islam sebagai satusatunya alternatif bagi kebangkitan Islam dan manuisa. Bagi mereka, Islam telah mencakup segala aspek kehidupan sehingga tidak memerlukan segala teori dan metode dari luar, apalagi barat. Garapan utamanya adalah menghidupkan kembali Islam sebagai agama, budaya sekaligus peradaban dengan menyerukan untuk kembali pada sumber asli (al-qur'an dan sunnah) dan mempraktekkan ajaran Islam sebagaimana yang dilakukan Rasul dan Khulafa'al-Rasyidin. Tradisi dan sunnah Rasul harus dihidupkan kembali dalam kehidupan modern sebagai bentuk kebangkitan Islam. (Misbachuddin, 2010).

Kedua, tradisionalis (salaf). Yaitu model pemikiran yang berusaha berpegang pada tradisi-tradisi yang telah mapan. Bagi mereka, segala persoalan umat telah diselesaikan secara tuntas oleh para ulama terdahulu. Tugas kita sekarang hanyalah menyatakan kembali atau merujukkan dengannya.

Ketiga, reformis. Yaitu model pemikiran yang berusaha merekonstruksi ulang warisan budaya Islam dengan cara memberi tafsiran baru. Menurut mereka, Islam telah mempunyai tradisi yang bagus dan mapan.

Keempat, posttradisionalis. Yaitu model pemikiran yang berusaha mendekonstruksi warisan Islam berdasarkan standar modern. Model ini sesungguhnya sama dengan reformis yang menerima tradisi dengan interpretasi baru. Perbedaannya, posttradisionalis mempersyaratkan dekonstruktif atas tradisi, bukan sekedar rekonstruktif sehingga yang absolut menjadi relatif dan ahistoris menjadi historis. (Misbachuddin, 2010)

Kelima, modernis. Yaitu model pemikiran yang hanya mengakui sifat rasional-ilmiah dan menolak kecenderungan mistik. Menurutnya, tradisi masa lalu sudah tidak relevan sehingga harus ditinggalkan. Karakter utama gerakannya adalah keharusan berpikir kritis dalam soal keagamaan dan kemasyarakatan. Mereka biasanya banyak dipengaruhi cara pandang marxixme. Meski demikian mereka bukan sekuler. 
Wanita mempunyai kedudukan sama dengan laki-laki kecuali dalam beberapa hal yang harus disesuaikan dengan nalurinya. Karenanya, dalam hal ini wanita memperoleh prioritas untuk dimuliakan dan diperlakukan lemah lembut sebagaimana layaknya. Keberadaan wanita dalam Islam yang begitu sempurna ini tidak dijumpai dalam agama lain. Islam sebenarnya tidak melarang seorang wanita bekerja atau melakukan kegiatan di luar rumah asal tidak melampaui batas kodrat kewanitaannya.

Mudah-mudahan wanita muslimah tetap berpegang dan berpijak di atas kodrat kewanitaan yang terlepas dari virusvirus karierisasi yang semakin mengancam pudarnya fungsi dan kedudukan wanita. Semoga kaum wanita tidak semakin lengah oleh belaian harta yang siap menghimpit tangantangan halus wanita. Di saat itu jualah wanita akan terpana oleh gemerlapnya dunia dan melupakan kodratnya sebagai wanita.

\section{Penutup}

Islam sebenarnya tidak melarang seorang wanita bekerja atau melakukan kegiatan di luar rumah. Hanya saja ada beberapa hal yang harus diperhatikan, yaitu:

1) Pakaian harus sesuai dengan aturan Islam;

2) Tidak melalikan tugasnya sebagai ibu rumah tangga;

3) Tidak menurunkan martabatnya sebagai wanita dan sesuai dengan fitrah dan kejiwaan wanita pada umumnya;

4) Tidak melanggar ajaran Islam mengenai hubungan antar pria dan wanita;

5) Dengan persetujuan suami.

\section{Daftar Pustaka}

Ali, K. Sejarah Islam (Tarikh Pramodern), Ed.1, cet.2. Jakarta: PT Raja Grafindo. 1997

Demakislam, "Emansipasi, Propaganda untuk Meruntuhkan Aqidah". Situs Demakislam, http://demakislam.wordpress.com/2009/11/10/emansipa si-propaganda-untuk-meruntuhkan-aqidah. Online 30 Mei 2011

Departemen Agama Republik Indonesia. Al-qur'an dan terjemahnya. Jakarta: Pers 1985 
Fadjar, Abdullah. Peradaban dan Pendidikan Islam, ed.I cet.1. Jakarta: Rajawali Pers. 1991

Hamka. Sejarah Umat Islam III, Cet.IV. Jakarta: Bulan Bintang. 1981

Mahmudunnasir, Syed. Islam Konsepsi dan Sejarahnya. Bandung: Remaja Rosdakarya. 1993

Misbachuddin. Sebuah Perkembangan Pemikiran Kontemporer Dunia Islam di Indonesia. Situs pribadi Misbachuddin, http://misbachuddin84.blogspot.com/2010/03sebuahperkembangan-pemikiran.html. Online 30 Mei 2011

Muslimah. Wanita antara Pembela dan Pencela. Situs muslimah. $\quad$ http://muslimah.or.id/akhlak-dannasehat/wanita-antara-pembela-dan-pencela-4.html. Online 30 Mei 2011

Nasution, Harun. Pembaharuan dalam Islam Sejarah Pemikiran dan Gerakan. Cet.10. Jakarta: Bulan Bintang. 1994

Newryl. Emansipasi adakah dalam Islam?. http://newry.wordpress.com/2011/02/18emansipasiadakah-dalam-islam. Online 30 Mei 2011

Qasim Aimn. Emansipasi wanita. Google=Emansipasi Wanita. http://www.google.co.id. Online 30 Mei 2011

Susenos. Memahami Sesungguhnya Arti Emansipasi Wanita dalam Islam. Situs pribadi Susenos. http://susenoscryingheart2.blogspot.com/2010/05/memahamisesungguhnya-arti-emansipasi.html. Online 25 Mei 2010 Watt, Montgomery. Kejayaan Islam: Kajian Kritis dari Tokoh Orientalis. Cet.1. Yogyakarta: Tiara Wacana. 1990

Yatim, Badri. Sejarah Peradaban Islam. Edisi I cet 4. Jakarta: Raja Grafindo. 1996 